социология

DOI: $10.17805 /$ trudy.2019.5.1

\title{
СОЦИАЛЬНЫЙ ПОРТРЕТ СОВРЕМЕННОЙ МОЛОДЕЖИ, ИМЕЮЩЕЙ ТАТУИРОВКИ
}

\author{
М. Г. Солнышкина, Я. М. Шошина \\ Московский гуманитарный университет
}

\begin{abstract}
Аннотация: В статье разработана структура социального портрета современной молодежи, имеющей татуировки, выделены доминантные характеристики. С позищий рассмотрения татуировок как элемента молодежной субкультуры особое внимание уделено аксиологическим показателям социального портрета. Выявлены проблемные характеристики социального портрета молодежи, имеющей татуировки как факторы риска развития личности, проведен их анализ.
\end{abstract}

Ключевые слова: молодежь; социальный портрет; татуировки; тату-зависимость

\section{SOCIAL PORTRAIT OF MODERN YOUNG PEOPLE WITH TATTOOS}

\author{
M. G. Solnyshkina, Ya. M. Shoshina
}

Moscow University for the Humanities

\begin{abstract}
The article develops the structure of the social portrait of modern young people with tattoos and highlights the dominantcharacteristics. From the standpoint of considering tattoos as an element of a youth subculture, special attention is paid to the axiological indicators of a social portrait. The authors identify the problematic characteristics of the social portrait of young people with tattoos as risk factors for personality development, and carry out their analysis.
\end{abstract}

Keywords: youth; social portrait; tattoos; tattoo addiction

Под социальным портретом мы понимаем совокупность информации о статусном и ролевом наборе, нормативных требованиях к представителю определенной группы, мотивационной сфере данного типа личности с выделением его доминантных черт и характеристик, образе жизни, социальных настроениях, материальных возможностях, с учетом общего и особенного в поведении и деятельности. Социальный портрет как жанр социологического исследования позволяет выявить отличительные характеристики определенных социальных групп, а также выполнить интегрированное описание основных социальных, демографических, социокультурных 
Научные труды Московского гуманитарного университета 2019 № 5

характеристик портретируемой группы. Следует заметить, однако, что в научной литературе нет четко обоснованной методики исследования социального портрета.

Разработка социального портрета молодежи, имеющей татуировки проводилось на основании данных анкетирования (апрель 2019 г.). Анкета разработана в соответствии с операционализацией понятия «социальный портрет молодежи, имеющей татуировки» (Горшков, Шереги, 2012: 44), включающей следующие группы характеристик:

- базовые характеристики как объективные показатели, отражающие индикаторы многомерной социальной стратификации молодежи: гендерные, образовательные, профессиональные, по видам занятости, по уровню дохода;

- аксиологические, позволяющие выявить субкультурные тенденции молодежи, имеющей татуировки как особой подсистемы в общей системе культуры общества (Михайлова, 2004: 184). Молодежь рассматривается с позиций тезаурусной социологии как социальная группа, осваивающая и присваивающая социальную субъектность через выражение и отражение символического и предметного мира (Луков, 2012: 317).

В связи с социокультурными особенностями социализации молодежи в современном обществе (Ковалева, 2013: 333) в данном исследовании аксиологическим характеристикам уделено особое внимание. Аксиологический профиль социального портрета включает такие субъективные показатели, как мотивация нанесения тату; ценностные ориентации молодежи, имеющей татуировки; предпочтение источников информации в окружающей культурно-информационной среде; досуговые предпочтения; удовлетворенность отдельными элементами жизни (работой, отношениями в семье, с друзьями, знакомыми) в системе социального самочувствия индивида ${ }^{1}$.

Тип выборки - неслучайная, стихийная. Для проведения опроса были использованы «Google формы». Всего в исследовании приняли участие 171 респондент. По результатам исследования разработан обобщенный портрет современного представителя молодежи, имеющей татуировки: выявлено, что типичным представителем является женщина в возрасте 23 лет, с высшим образованием в должности специалиста или служащего. Она не относит себя ни к одной из субкультур, но из всего их многообразия максимально отождествляет себя с хипстерами $(24,6 \%)$. У нее имеется в среднем четыре татуировки, преимущественно на руках, ногах, спине и плечах, которые сделаны для украшения тела и реализуют желание показать свою

${ }^{1}$ Авторы выражают благодарность профессорам кафедры социологии МосГУ за содействие в разработки методологии и методики данного исследования. 
индивидуальность, особенности своего внутреннего мира (Филатова, 2009: 6). Она хотела бы сделать себе еще татуировки, рисунок которых также для нее символичен и не является случайным выбором. У большинства ее знакомых есть татуировки (88 \%). Она видит людей с татуировками чаще всего в интернете $(88 \%)$ и на улице $(75 \%)$. Наличие татуировок и их рисунок ее в значительной степени устраивает (69\%).

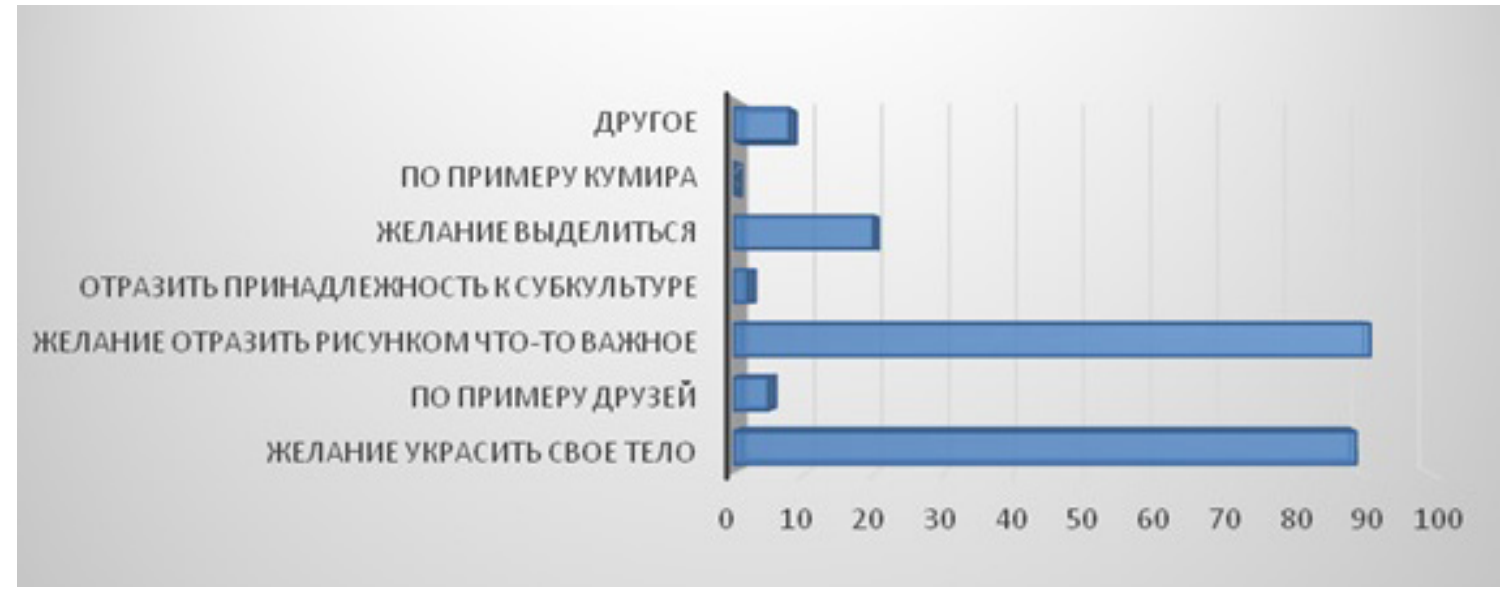

Рис. 1. Причины нанесения татуировки.

Graph 1. Reasons for getting a tattoo.

Типичный представитель молодежи с татуировками считает для себя ценным саморазвитие, испытывает удовлетворенность дружескими (75\%) и семейными отношениями (65\%), часто посещает общественные места (преимущественно парки - 75\%, кинотеатры - 51\%, фитнес-залы $-37 \%$.), любит свою работу (60\%). Выявлены довольно низкая удовлетворенность материальным положением (42\%) и критичный уровень доверия к органам государственной власти и управления (законодательной, исполнительной, судебным органам — от $11 \%$ до 18\%).

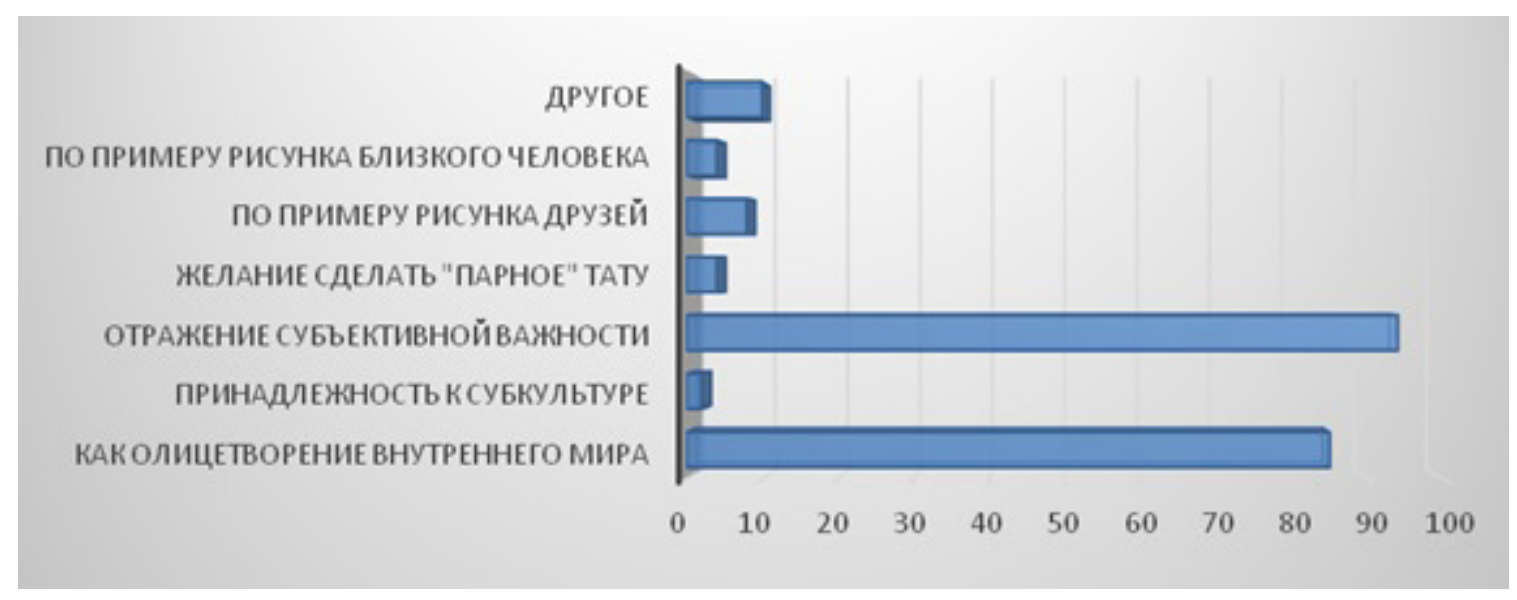

Рис. 2. Причины выбора определенного рисунка для татуировки. Graph 2. Reasons for choosing a certain picture for the tatoo. 
Не нашли своего подтверждения тенденции выраженной контркультурности и субкультурности (отнесение себя к определенной субкультуре в качестве мотивации нанесения татуировки - 1\%).

Среди доминантных характеристик социального портрета молодежи, имеющей татуировки, выявлены следующие проблемные зоны как факторы риска развития личности:

- формирование тату-зависимости, переходящей в тату-манию (уже имея в среднем четыре татуировки, у 93\% опрошенных есть желание делать еще татуировки). Нанесение тату причиняет боль, под действием которой организм начинает вырабатывать адреналин и люди стремятся получить это состояние вновь. Механизмы формирования тату-зависимости связаны также со стремлением привлечь к себе внимание и неумением выразить себя иными способами. Увлечение нанесением новых рисунков приводит к тому, что со временем тело превращается в хаотичное полотно разнообразных узоров, часто не сочетающихся между собой по выбранным стилям, сюжетам;

- недоверие молодежи к власти, которое демонстрирует тенденцию аполитичности молодежи, отказ от активных действий, направленных на реализацию своих политических прав и выполнение обязанностей. В России эта проблема проявляется остро как негативная тенденция в социальном портрете современной молодежи в эпоху трансформации общественных отношений. Социальная реальность такова, что часть молодых людей пассивна, в общественной жизни не участвует. Проблемными характеристиками современной молодежи являются низкая социальная активность, пассивное поведение, недоверие к органам власти, высоки эмиграционные настроения. (Горшков, Шереги, 2010: 38). У отдельной части молодежи проявляется иждивенческая позиция, нежелание создавать, формировать, развивать, наблюдается ориентация на получение готового продукта.

Эвристический потенциал использования полученных результатов исследований может быть реализован в следующих направлениях молодежной проблематики: изучение предметного и символического мира молодежи, ее смысложизненных ориентиров, системы ценностных ориентаций. В прикладных аспектах социальной практики полученные результаты актуальны для выявления социокультурных проблем молодежи, разработки технологий ее самореализации в культуре, а также при организации культурно-досуговой и патриотической работы с молодыми людьми в системе государственной молодежной политики, повышении ее адресности и эффективности. 


\section{СПИСОК ЛИТЕРАТУРЫ}

Горшков, М. К., Шереги, Ф. Э. (2010) Молодежь России: социологический портрет. М.: Институт социологии РАН. 592 с.

Горшков, М. К., Шереги, Ф.Э. (2012) Прикладная социология: методология и методы. М. : ФГАНУ «Центр социологических исследований. Институт социологии РАН. 404 с.

Ковалева, А. И. (2013) Новый взгляд на явление идентичности // Знание. Понимание. Умение. № 2. С. 322-323.

Луков, Вал. А. (2012) Теории молодежи: междисциплинарный анализ. М. : «Канон+» РООИ «Реабилитация». 528 с.

Михайлова, Л. И. (2004) Социология культуры : учебное пособие. М. : Издательско-торговая корпорация «Дашков и К». 344 с.

Филатова, С. В. (2009) Модные татуировки со всего света. М. : Издательский дом «РИПОЛ классик». 264 с.

Дата поступления: 12.09.2019 2.

Солнышкина Марина Георгиевна - доктор социологических наук, профессор, профессор кафедры социологии Московского гуманитарного университета. Адрес: 111395, Россия, г. Москва, ул. Юности, д. 5. Тел.: + 7 (499) 374-60-21. E-mail: solny2001@mail.ru

Шошина Ярослава Михайловна - выпускник факультета психологии, педагогики и социологии Московского гуманитарного университета. Адрес: 111395, Россия, г. Москва, ул. Юности, д. 5 . Тел.: +7 (499) 374-60-21. E-mail: shoshina.ya.m@gmail.com

Solnyshkina Marina Georgievna, Doctor of Sociology, Professor, Professor, Department of Sociology, Moscow University for the Humanities. Postal address: 5, Yunosti St., Moscow, Russian Federation, 111395. Tel.: +7 (499) 374-60-21. E-mail: solny2001@mail.ru

Shoshina Yaroslava Mikhaylovna, Graduate, Faculty of Psychology, Pedagogy and Sociology, Moscow University for the Humanities. Postal address: 5, Yunosti St., Moscow, Russian Federation, 111395. Tel.: +7 (499) 374-60-21. E-mail: shoshina. ya.m@gmail.com

\section{Для цитирования:}

Солнышкина М. Г., Шошина Я. М. Социальный портрет современной молодежи, имеющей татуировки [Электронный ресурс] // Научные труды Московского гуманитарного университета. 2019. №5. URL: http://journals.mosgu.ru/trudy/article/view/1150 (дата обращения: дд.мм.гг.). DOI: 10.17805/trudy.2019.5.1 